\title{
Capital Structure of Real Estate Firms in Chinese Stock Market
}

\section{Thian Cheng Lim}

BEM department, Xi'an Jiaotong-Liverpool University

111 Ren'ai Road, Dushu Lake Higher Education Town, Suzhou Industrial Park 215123, China

Tel: 86-(0)512-8816-1712

$$
\text { Dan } \mathrm{Zhao}^{1 *}
$$

111 Ren'ai Road, Dushu Lake Higher Education Town, Suzhou Industrial Park 215123, China Tel: (1)718-200-4296

$$
\text { Ruiyang } \text { Chai }^{2} *
$$

145 Forest Street, Waltham, Boston MA 02451 USA

Tel: $781-864-3089$ 


\section{ABSTRACT}

This paper investigates the determinants of capital structure of real estate firms in China. An empirical study on determinants of capital structure of real estate in Chinese listed firms is conducted using a relatively regression of accounting data for 44 A-share financial listed companies over the quarter from 2008 to the third quarter of 2011. First, this paper identifies that the pecking order theory in China is different from western countries. Second, the results show that profitability, non-debt tax shields and liquidity are significant influence factors in financial sector, while others like size, growth, tangibility and non-circulating share should be judged by the size of the company. Moreover, firm size and non-circulating shares are almost positively related to the corporate leverage ratio. It is also found that Chinese institutional characteristic affects the capital choice decision and the largely state ownerships do affect capital structure choices.

Keywords: China, real estate firms, capital structure, theory, leverage, financing characteristic.

\section{INTRODUCTION}

Real estate industry is the pivotal industry in national economy. The rapid growth of the real estate markets (both in quantity and property appreciation rates) in Chinese cities provides us an opportun ity to examine the influence of capital structure on the real estate industry (Brandt and Rawski, 2008). Over the past 10 years, Chinese real estate markets have joined the global universe of investable assets as exemplified by vibrant skylines and the construction of startling commercial properties in Chinese megacities. It is now difficult to ignore a market ranked as the third largest globally by invested stock (DTZ, 2012). This becomes evident after the 2008 financial crisis and the large amount of liquidity injected by the government went into real estate.

Capital Structure not only affects the cost of capital and market value of the firm, but also the corporate governance and the integral operative performance. Capitalization ratio delivers the key in sights to evaluate a company's capital position. Therefore, analysts use different ratios to assess the financial strength of a company's capital structure. Firms raise investment capital through several sources such as initial public offerings (IPO), seasoned offerings of common stock and preferred stock which comes under equity or alternatively they raised debt. The choice of funding sources is dependent on firms' capital structure, relative cost of funds, and possibly market value of firm's securities. Several theories have attempted to explain firms' choice of securities, but there was no consensus on this is sue.

Lately, more and more China's real-estate enterprises raised funds from the capital market. They issue stocks and turned themselves into listed public companies. But they remain controlled by some small group of investors mainly state owned enterprises or families. Therefore it is necessary and significant to conduct a study of the problem of optimization of the capital structure of the listed real estate companies. Despite of western theories and models that influence firm's capital structure, what determine the capital structure of real estate firms in China had been a question to academic and practitioners alike. Therefore, this paper study the capital structure of real estate companies listed on the Chinese stock market to determine what affect capital structure decisions of real estate firms. 
Lu \& Xin (1998) and Guo \& Sun (2003) found that industry factors dramatically affect the capital structure of listed companies in China. Within the industry these factors also can influence how a firm chooses to raise its capital? The factors are as follows: Profitability, Tangibility, Firm Size, Non-debt Tax Shields, Growth Opportunities, Liquidity, and Ownership Structure.

Chen (2009) discovered that assets liabilities ratio in real-estate industry has been keeping increasing by degrees, with an average ratio $56.99 \%$ in 2003, 59.27\% in 2004 and 59.28\% in 2005; while, in other industries, it stays at around $40 \%-50 \%$. This indicates that most of the capital in real-estate industry relies on debt, which is the feature of the industry. In China, lack of capital is a common problem in the real estate industry; therefore most of its capital comes from bank loan, earnest money, advance receipts and outer investment. There is little capital from its own. This results in over dependence on loan and advance receipts and deep assets liabilities ratio.

This paper will mainly focus on the capital structure of real estate in Chinese listed companies to investigate the impacts of different measures or determinants on the choices of capital structure and attempt to point out the optimal capital structure for real estate firms in Chinese listed companies. Subsequently, the econometrics models such as static panel data model and dynamic panel data model will be adopted to analyze the data.

\section{Literature Review}

\subsubsection{Modern Theories of Capital Structure}

Modern finance theories on capital structure are dominated by these three famous western theories; MM, trading off theory (TOM) and pecking order theory (POT).

Modigliani and Miller (1958) points out one of the most classical modern theories which indicates that, in a perfect capital market, the value of enterprise is irrelevant with the firm's capital structure. This theory assumes that there are no bankruptcy costs, individuals can borrow and lend at the risk-free rate and there are only two types of finance which is risk-free debt and risky equity. In the hypothes is of MM theory, all firms are in the same level of risk, no growth, symmetry information and no agency costs.

Trade off theory was put forward by Scott (1977) demonstrating that as the increase of the ratio of bonds, the risk of the company will also increase, thus raising the bankruptcies, then decreasing the value of the company. Therefore, the optimu m capital structure of company should be the equilibriu m point caused by financial crisis cost and bankruptcy cost between section tax benefit and the rise of ratio of debt capital. 
In 1984, Myers and Majluf carry out pecking order theory considering the impact of information sources between insiders and outside investors on the corporation investment and financing behaviors. Due to adverse selection, they illustrate the retained earnings as the internal funds dominated the first place in the corporate financing preference, followed by debt financing and equity financing. When outside funds are necessary, firms prefer debt to equity because of lower information costs associated with debt issues. As an alternative capital structure theory, pecking order theory takes account of the asymmetric information and the existence of transaction costs.

From the asymmetric information perspective, it could be imagined that manager, as the insider, could access more relevant and reliable information about firms than the less informed outside investors. With the information advantage, managers could have more opportunity to is sue bonds thus avoiding adverse signaling information of issuing equity. This theory is usually regarded as a competitor to the Trade-off theory.

Baker and Wurgler (2002) also suggest a new theory of capital structure: the "market timing theory of capital structure". This theory argues that firms time their equity issues in the sense that they issue new stock when the stock price is perceived to be overvalued, and buy back own shares when there is undervaluation. Consequently, fluctuations in stock prices affect firms' capital structures. They find that leverage changes are strongly and positively related to their market timing measure, so they conclude that the capital structure of a firm is the cumulative outcome of past attempts to time the equity market.

Fama and French (2002) have attempted to compare TOM and POT, indicating that although the rate of the adjustment is quite slow, regressions of firms' debt ratios show reliable evidence that leverage is mean-reverting. Hackbarth et al. (2007) argues that the TOM is not only able to measure a certain debt level, but also could infer the optimal debt structure in terms of bank and market debt to borrow or is sue.

\subsection{Capital Structure Research in China}

Wang (2003) characterizes Chinese listed real estate companies with lower leverage level, lower long-term debt ratio, and higher equity over fixed as sets ratio and unique mixed ownership structure due to the undeveloped corporate bond market and the ownership structure. Dai (2004) tests 35 real estate listed companies in China 2000-2002, with the exception of the corporate velocity showing variables of firm characteristics are almost not related to capital structure which has significant negative relation to short-term debt ratio. Li, Luo, \& Ao (2005) put forward the real estate companies in China have state-owned stock with high liability according to the 46 real estate listed companies in 2003. 
In contrast to Booth et al. (2001), who has examined the capital structure in developing countries are similar to developed countries using market-based economic models, Chen (2004) demonstrates that the modern theories of capital structure are less applicable to the financing choice of Chinese firms, showing a new Pecking order for financing with the first consideration of internal fund, then equity financing and lastly long-term debt. Huang and Song (2006) exercise a new data set more than 1000 Chinese listed companies to analyze the capital structure models in over the period 1994-2000, with the same findings as Booth et al. (2001) that firms in developing countries tend to have lower long-term debt.

Qian et al. (2007) have examined the six determinants of capital structure for Chinese listed companies over the period of 1999-2004, which have validated the work Chen and Huang \& Song. The static panel-data models showed that firm size, tangibility and state ownership are positively related with firm's leverage ratio. However, factors such as profitability, non-debt tax shields and volatility have a negative relationship with the leverage ratio. Li (2010) make an empirical study to investigate the determinants of capital structure of real estate in Chinese listed firms during 2003-2007. The finding shows that institutional differences and financial constraints in the capital markets have also significantly con stituted to the influencing factors for companies' capital structure.

\section{RESEARCH METHODOLOGY}

The research method of this empirical study involves the econometrics model with a series of Descriptive Statistic Analysis and quantitative methods from the Ch inese listed companies' financial and accounting database. Due to the data limitation of state-owned share percentage and fixed assets ratio, the analysis is conducted by using a panel data linear regression model where the dependent variable is leverage ratio during the time period from the first quarter of 2008 to the third quarter of 2011. In this paper, static and dynamic panel data models will be used, and the results from these two models will be run in the STATA program in the following empirical analysis.

\subsection{Static Panel Data Model}

The initial basic regression model for analyzing panel data is the ordinary least squares regression (OLS). The formulation of this model in mathematics is:

$y_{i t}=\alpha+x_{i t}^{\prime} \beta+\varepsilon_{i t}, i=1,2, \ldots 44 ; t=1, \ldots 12$

In this model, $y_{i t}$ represents the capital structure of real estate firm i in year $\mathrm{t} ; \quad \alpha$ is the constant term; $x_{i t}^{\prime}$ is a $1 \times 7$ vector of seven independent variables which is the explanatory indicators; $\beta$ is coefficient vector of parameters which is independent variables that is constant over quarters; $\varepsilon_{i t}$ is the unobserved error term or disturbance term. In Table 1, we have extracted the main variables from $\mathrm{Li}$ (2010). In terms of the literature review and research objectives, the regression model is going to be constructed as following expression:

$\mathrm{LEV}=\mathrm{f}(\mathrm{FS}$, Pro, GO, Tan, Liq, NTS, NCS $)$ 
LEV is the dependent variable represents the debt ratio with the size of total assets. In the bracket, there are seven independent variables: FS: Firm Size, Pro: Profitability, GO: Growth Opportunity, Tan: Tangibility, Liq: Liquidity, NTS: Non-tax shields, NCS: Non-Circulating Shares.

The practical and theoretical reasons why we use the OLS estimators is due to the dominant method used in practice. OLS has become the common language for regression analysis throughout economics, finance and social sciences more generally. The using OLS presents results indicating that you are 'speaking the same language' as other economists and statisticians. The OLS formulas are built into virtually all spreadsheet and statistical software packages, making OLS easy to use. The desirable theoretical properties are also the advantages of OLS estimators. The OLS estimator is unbiased and consistent which is also efficient among a certain class of unbiased estimators; however, additional special conditions need to be discussed and more result analysis should be deferred (Stock and Watson, 2007).

\subsection{Dynamic Panel Data Model}

Dynamic PDM contains a lagged dependent variable as a regression. It considers a dynamic model with variable intercepts. Take the following equations as an example:

$y_{i t}=\mu+\rho y_{i, t-1}+x_{i t}^{\prime} \beta+z_{i}^{\prime} \gamma+u_{i t}$

In the above equation, $y_{i t}$ is the dependent variable of unit i at time $\mathrm{t} ; \quad \rho$ is the dynamic coefficient with $-1<\rho<1$; $y_{i, t-1}$ is the lagged dependent variable of unit $\mathrm{i}$ at time $\mathrm{t} ; x_{i t}^{\prime}$ is time-vary ing strictly exogenous variables; $z_{i}^{\prime}$ is time-invariant strictly exogenous variables; $u_{i t}$ is an idiosyncratic component; $\mu$ is the error term which includes a fixed effect component; $\beta$ and $\gamma$ are the coefficient vectors of $x_{i t}^{\prime}$ and $z_{i}^{\prime}$ respectively.

There are three key assumptions for the linear regression model. First, the regression errors $u_{i t}$ should have a mean of zero conditional on the regressors $x_{i t}^{\prime}$; second, the sample observations are i.i.d. random draws from the sample; third, large outliers are unlikely. If these assumptions hold, the OLS estimators are unbiased, consistent and normally distributed when the sample is large.

The lagged dependent variable is weakly exogenous. Thus, strict exogeneity cannot hold in a dynamic model. The dynamic coefficient is of central interest in estimation. Therefore, in general, the least square estimators are biased and inconsistent if time is finite. However, instrumental-variables approach can provide a consistent estimator for dynamic PDM.

The symptom of dynamic PDM is quite lagged, thus the impact of the independent variables on the capital structure of 
the firm and the debt ratio of the firm can't response to the current change in company situation. Therefore, the independent variables in the earlier periods could have impacts on the debt ratio.

Ahn and Schmidt (1995) introduce a GMM (Generalized Method of Moments) framework to utilize all available mo ment conditions understandard assumptions. This study will apply optimal GMM estimation by using longer lags of the dependent variable as additional instruments. In the empirical study of $\mathrm{Li}$ (2010), pointing out because of linear correlated with the error term due to the structure of fixed effect model, the capital structure of the firm in the last year can be determined as endogenous. The endogenourity of the other variables could be tested by computing the correlation and some other specific tests in the model.

\subsection{Data Collection}

This empirical research will adopt Descriptive Statistic Analysis to fully explore the feature of capital structure for Chinese listed real estate firms. This quantitative study collects a data set from Chinese listed companies in real estate industry which is fixed in quarter period between 2008 and 2011. The main data source comes from CINIFO with the copyright of Shenzhen Securities Information Co., Ltd. Other supporting source of data set is China Stock Market and Accounting Research Database (CSMAR) developed by Shenzhen GTA Information Technology Co. in China. Only 44 listed companies of Chinese real estate firms from A-share companies are chosen from Shanghai and Shenzhen stock exchanges with amounts of 24 and 20 real estate firms respectively. It excludes ST and PT companies due to incomplete data and abnormal in their finance in avoiding to influence our conclusion.

Since Huang \& Song (2006) has summarized the determinants of capital structure, it theoretically predicted signs and the results of previous empirical studies. Chen (2009) used capital structures of the 27 companies from 2003 to 2005 and the quantitative study of $\mathrm{Li}$ (2010) uses an unbalanced panel data set of both market and accounting data in time period of 2003-2007 for real estate companies listed in Shanghai and Shenzhen stock markets including following variables: size, profitability, growth, tangibility, liquidity, tax-shield and state own shares.

Therefore, this study is going to follow the literatures and check whether the initial theoretical results are still compatib le with the current capital structure of the real estate firms in Chinese markets.

\section{RESULTS AND DISCUSSION}

As for the big real estate firms, there is a negative relationship between profitability, growth, tangibility, liquidity and non-debt tax shields to the leverage. There is a positive relationship between size and non-circulating shares to the leverage. It proves that the growth and tangibility are the non-significant variables in this regression.

According to the above negative relationship, it demonstrates that high leverage company has low profitability, growth 
and high level of bankruptcy. Due to that, they have to incur more debt, because if higher leverage companies want to issue shares, not many people will be interested in buying the shares. Thereby, the only option for the high leverage company is to issue debt, because if the companies are profitable, they don't need to raise finance.

In this case, debt is the last choice, because the company has retained earnings. This is in line with the findings in this paper where the first choice of capital in China is equity, and debt is the last choice. Therefore, only company without much profitability and growth will have to borrow money from the debt market. In this case, most of the debts come from the banks. Big real estate companies mainly in China are controlled by the government, they are not like the real shareholder. The companies actually are from their parent which is the government.

As for the s mall real estate firms, there is a negative relationship between size, profitability, growth, tangibility, liquidity and non-debt tax shields to the leverage. Only non-circulating shares have the positive relationship with the leverage. While, in this regression, growth, tangibility and non-circulating shares are the non-significant variables.

Based on the positive relationship of non-circulating shares to the small leverage real estate firms, it could be judged that most of the s mall real estate companies are not state owned enterprises. They are s mall enterprises who don't have major banks support them due to the non-significant of the non-circulating shares in the regression.

The positive relationship between size and non-circulating share represent they are state own enterprise. The large real estate companies are mainly own by the government. Thus, if they are profitable, the government will buy their share that is why the equity is the first choice, because they can sell the shares to the gov ernment very easily and quickly. Un like the small companies, they have to sell the shares to the public.

As to the whole sample size of the real estate firms in China, there is a negative relationship between profitability, growth, tangibility, liquidity, non-debt tax shields to the leverage, while there is a positive relationship between size and non-circulating shares to the leverage. In this regression, size, growth and tangibility are non-significant variables.

Large companies are more dominant because there is more large company in the market place. China real estate companies are dominated by the large company. Our findings show that China real estate industry is controlled or dominated by large companies. When analyzing whether and how strongly operating risk affects leverage, it shows that firms with a high level of operating risk have lower leverage, due to the purpose to maintain a moderate total risk profile, avoiding to adding financial risk.

\section{CONCLUS ION}

The results show that the real estate firms in China choose equity financing first, then debt financing and the last choice 
is the internal financing. This is opposite of the pecking order theory which suggest that firm choose internal financing, debt and lastly equity. In China many real estate firms are government owned and therefore they have advantages in raising capital through issuing of stocks. Since minority shareholders do not demand high dividend, it is a relatively cheap way of raising capital.

Second, there is a negative relationship between profitability, growth, tangibility, liquid ity and non-debt tax shields to the leverage ratio for the big real estate firms. There is a positive relationship between size and non-circulating shares to the leverage. This means that large firms have low nu mber of available shares for trade which suggest that they are owned by large shareholders in China case most likely State own enterprise (SOE).

Compared to the s mall real estate firms, there is a negative relationship between size, profitability, growth, tangibility, liquidity and non-debt tax shields to the leverage ratio. Only non-circulating shares have the positive relationship with the leverage. Hence, when combing the big and small real estate firms together, there is a negative relations hip between profitability, growth, tangibility, liquidity, non-debt tax shields to the leverage, while there is a positive relationship between size and non-circulating shares to the leverage.

Third, this empirical study proves that the growth and tangibility are the non-significant variables in this regression in the big real estate. While, in the s mall real estate firms, growth, tangibility and non-circulating shares are the non-significant variables. A combination of the big and small firms indicates that the size, growth and tangibility are non-significant variables.

\section{REFERENCES}

[1] Ahn SC, Schmidt P (1995) Efficient Estimation of Models for Dynamic Panel data. Journal of Econometrics, 68: $5-27$.

[2] Booth L, Aivazian V, Demirguc-Kunt A, Maksimovic V (2001) Capital Structures in Developing Countries. Journal of Finance, 1(56): 87-130.

[3] Brandt L, Rawski TG (2008) China's Great Economic Transformation. Cambridge: Cambridge University Press. Available at: $\underline{\text { http://homes.chass.utoronto.ca/ floyd/newsletter/bransky.pdf }}$

[4] DTZ Research (2012) The Great Wall of Money, Available at: http://www.dtz.com/Global/Research (March 11, 2012) 
[5] Chen JJ (2004) Determinants of capital structure of Chinese-listed companies. Journal of Business Research, 57: 1341-1351.

[6] Chen SQ (2009) Capital Structure of Listed Company in China: Based on Real Estate Industry. Jiangsu Teachers University of Technology.

[7]CNINFO (2011) Shenzhen Securities Information Co., Ltd. [Online] Available at: http://www.cninfo.com.cn/default.htm (Nov 29, 2011)

[8] Dai Y (2004) Empirical Analysis on Influencing Factors of Capital Structure: The Case of China Real Estate Listed Companies. China-USA Business Review, 3 (4): 1-6.

[9] Guo PF, Sun PY (2003) The Industry Characteristics: An Empirical Study Based on Listed Companies in China [J]. Economy Research, (5).

[10] Huang G, Song FM (2006) The Determinants of Capital Structure: Evidence from China. China Economic Review, 17: $14-36$.

[11] Li LF (2010) What factors might explain the capital structure of listed real estate firms in China? Department of Real Estate and Construction Management, Thesis no.26.

[12] Li P, Luo Q, Ao L (2005) The analysis of capital structure of Chinese real estate listed companies. Journal of Harbin Institute of Technology, 12(3): 291-294.

[13] Lu ZF, Xin Y (1998) Demonstrational research of influence factors of listed companies capital structure [J]. Accounting Research, 34-37.

[14] Qian Y, Tian Y, Wirjanto TS (2007) An empirical investigation into the capital-structure determinants of publicly listed Chinese companies: A static analysis. University of Waterloo.

[15] Stock JH, Watson MW (2007) Why has U.S. inflation become harder to forecast? Journal of Money, Credit and Banking, 39(1): 3-33.

[16] Wang VH (2003) The Capital Structure Management of Chinese Listed Real Estate Companies. Department Of Building and Real Estate Economics, Div. of Real Estate and Construction Management. Royal Institute of Technology, 
Master of Science Thesis number 209. 